\title{
Nasal Plasmablastic Lymphoma in an HIV-Negative Immunocompetent Patient
}

\author{
HIV Negatif Immünokompetan Bir Hastada Nazal Plazmablastik \\ Lenfoma
}

\author{
Nadhirah Mohd SHAKRI $\odot$, Salina HUSAIN $\odot$, Farah Dayana ZAHEDI $\odot$, Geok Chin TAN $\odot$
}

Ethics Committee Approval: Not Applicable.

Conflict of Interest: The authors declare that they have no conflict of interest.

Funding: None.

Informed Concent: Informed consent was taken.
Cite as: Shakri NM, Husain S, Zahedi FD, Tan GC. Nasal Plasmablastic Lymphoma in an HIV-Negative Immunocompetent Patient. Medeniyet Med J. 2020;35:71-4.

\begin{abstract}
Plasmablastic lymphoma (PBL) is a rare and aggressive variant of diffuse large B-cell lymphoma predominantly in oral cavities of human immunodeficiency virus (HIV)-positive male patients or immunosuppressive hosts. Limited number of reports on HIV-negative PBL in immunocompetent patients are available in the literature. We reported an unusual case of sinonasal PBL which occurred in an HIV-negative and immunocompetent female patient. She underwent endoscopic removal of the tumor and completed 6 cycles of chemotherapy (hyperfractionated-CVAD). Any finding in favour of tumour recurrence was not observed in positron-emission tomography scan (PET-scan) performed 18 months after the treatment.
\end{abstract}

Keywords: Non-Hodgkin lymphomas, plasmablastic lymphoma, sinonasal

\section{Öz}

Plazmablastik lenfoma (PBL), genellikle insan immün yetmezlik virüsü (HIV) pozitif erkek hastaların veya immünsüpresif konakların oral kavitesinde görülen, diffüz büyük B-hücreli lenfomanın nadir ve agresif seyirli bir varyantıdır. Literatürde immünokompetan hastalarda HIV negatif PBL ile ilgili bildiriler oldukça sınırlıdır. Çalışmamızda HIV negatif ve immünokompetan bir kadın hastada oluşan nadir bir sinonazal PBL vakası sunduk. Hastaya tümörün endoskopik rezeksiyonu yapıldı ve 6 kür kemoterapi (hiperfraksiyone-CVAD) uygulandı. Tedavi sonrası 18. ayda yapılan pozitron emisyon tomografi (PET) taramasında tümör rekürrensi lehine bir bulgu gözlenmedi.

Anahtar kelimeler: Non-Hodgkin lenfomalar, plazmablastik lenfoma, sinonazal
Received: 18 November 2019

Accepted: 6 February 2020

Online First: 28 February 2020

Corresponding Author:

N.M. Shakri

ORCID: 0000-0003-4939-2562

Universiti Kebangsaan Malaysia

Medical Centre, Department of

Otorhinolaryngology - Head and Neck Surgery,

Kuala Lumpur, Malaysia

nadhirahshakri@gmail.com

ORCID: 0000-0001-7683-2143

F.D. Zahedi

ORCID: 0000-0002-8725-0111

Universiti Kebangsaan

Malaysia Medical Centre,

Department of Otorhinolaryngology

- Head and Neck Surgery,

Kuala Lumpur, Malaysia

G.C. Tan

ORCID: 0000-0002-2289-7619

Universiti Kebangsaan

Malaysia Medical Centre,

Department of Pathology,

Kuala Lumpur, Malaysia 


\section{INTRODUCTION}

Plasmablastic lymphoma (PBL) is an uncommon and aggressive large $\mathrm{B}$-cell neoplasm which is predominantly reported in HIV-positive male patients ${ }^{1-3}$. Described as having high association with human immunodeficiency virus (HIV) and Epstein-Barr virus (EBV) ${ }^{1}$, PBL is commonly reported in the oral cavity, followed by gastrointestinal tract, lymph nodes and skin². Most of the patients are lost due to fulminant metastatic disease within the first year of diagnosis due to its aggressiveness and poor response to therapy ${ }^{4}$. It has been suggested that HIV-positive patients with PBL have better prognoses as compared to HIV-negative patients ${ }^{4,5}$.

To date, no standard guideline has been established for the treatment of PBL. Chemotherapy with cyclophosphamide, doxorubicin, vincristine, and prednisolone (CHOP) and cyclophosphamide, vincristine, doxorubicin, and dexamethasone (CVAD) are the most widely used treatment regimens. The sinonasal cavity is an unusual location for PBL, and only sparse cases, in HIV-negative male patients concerning the maxillary sinus and nasal septum, have been reported ${ }^{6,7}$.

\section{CASE REPORT}

A 56-year-old HIV-negative female patient presented with profuse right epistaxis requiring blood transfusion. The patient had two months history of right-sided nasal congestion despite medical treatment, and endoscopic examination revealed a friable, reddish mass occupying the right nasal cavity. Otherwise, she denied any B-symptom. Computed tomography showed that the mass filled the right nasal cavity, caused thinning of the posterior part of the nasal septum, and extended posteriorly into the nasopharynx (Figure 1). In addition, there was an enlarged lymph node, which was measured $3 \times 3.4 \mathrm{~cm}$ in size at level IV on the right side of the neck.

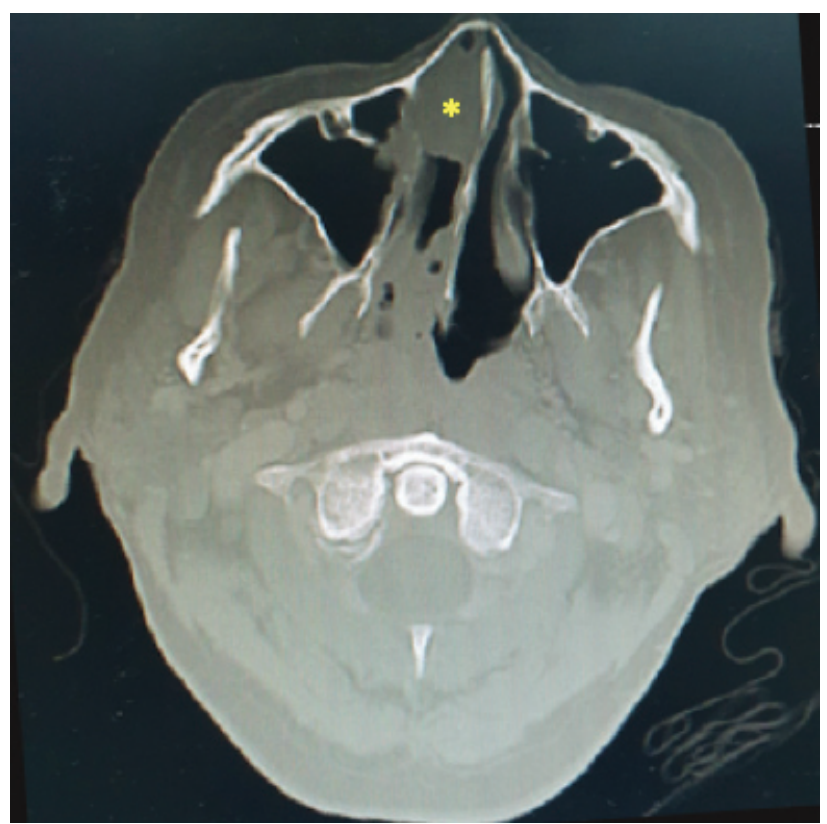

Figure 1. Preoperative CT scan revealed enhancing lesion (asterisk) with the epicentre occupying and widening the right nasal cavity. Medially it causes nasal septum deviation to the left and thinning of the posterior part of the septum. The lesion extends posteriorly to the nasopharynx.

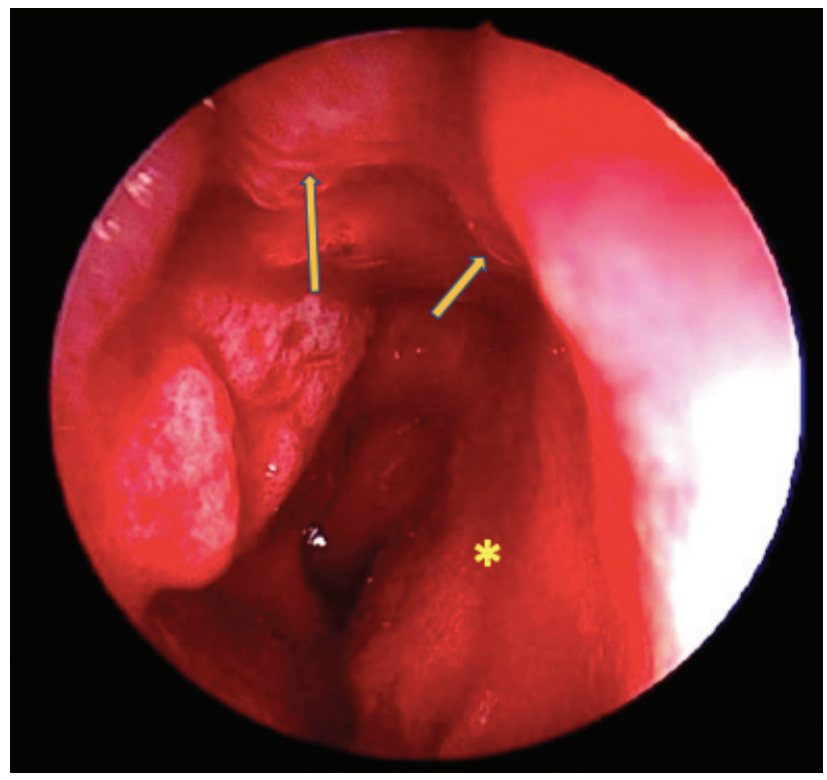

Figure 2. Intraoperative endoscopic examination of the right nostril. The remnant of the friable reddish mass (long arrow) is seen originated and flushed with the posterior part of right nasal septum (short arrow). The mucosa of the right nasal septum (asterisk) is unhealthy.

The patient was taken to the operating theatre and endoscopic examination under general anesthesia (GA) revealed the tumor originated from the pos- 
terior part of the right nasal septum (Figure 2). The tumor was friable and bled to touch. Biopsy of the tumor performed and remnant of the tumor was debrided. The hemostasis was secured with coblator and adrenaline-soaked ribbon gauze. Histopathologic examination revealed that the tumour was composed of highly cellular infiltrative malignant lymphoid cells arranged in solid sheets. These cells had large, markedly pleomorphic, vesicular nuclei, some eccentrically located, open chromatin with large prominent nucleoli, and abundant cytoplasm (Figure 3A). Mitotic figures and apoptotic bodies were frequently observed. An immunohistochemical study showed that the malignant cells

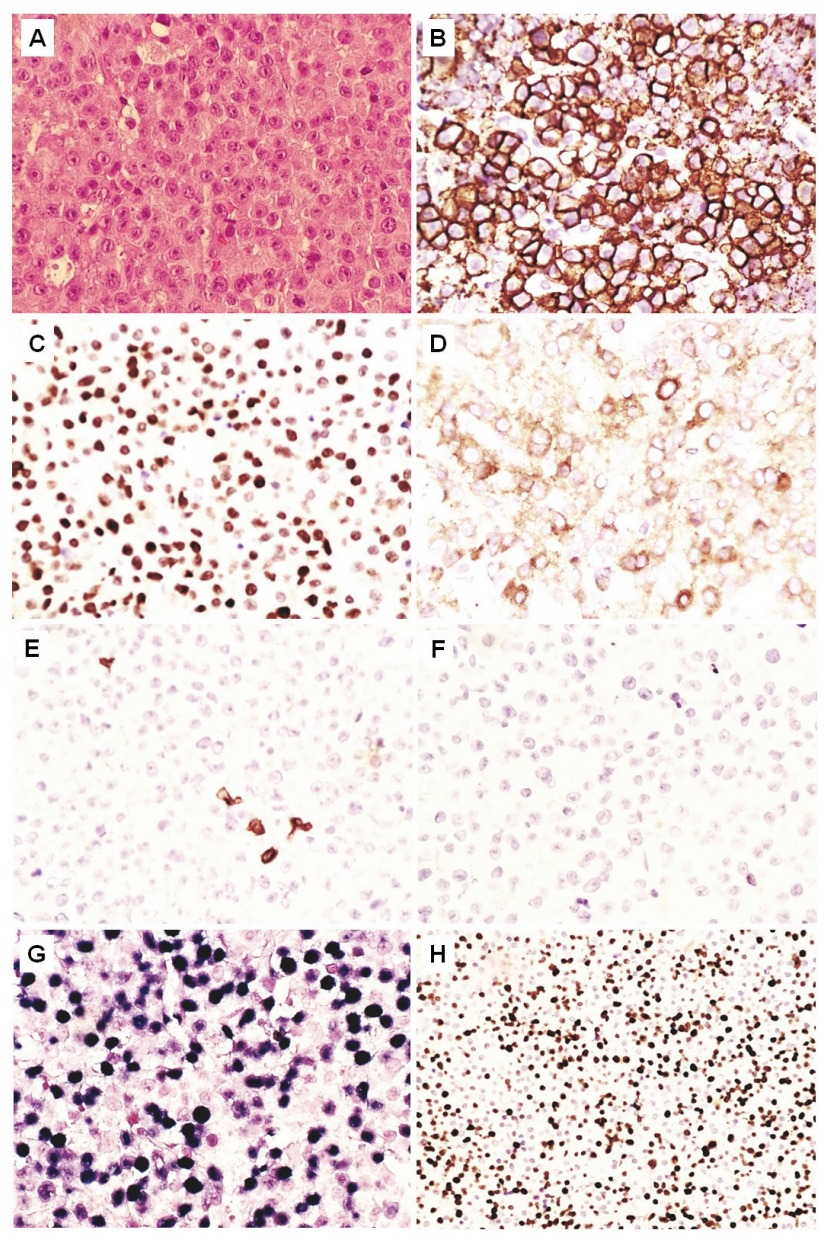

Figure 3. Histopathologic examination. The malignant cells are arranged in solid sheets and display large, pleomorphic nuclei with large prominent nucleoli and abundant cytoplasm (A). These cells are immunoreactive toward CD138 (B), MUM1 (C) and CD79a (D), and are negative for CD3 (E) and CD20 (F). EBER-in situ hybridisation is positive (G) and Ki-67 proliferative index is high $(\mathrm{H})$. were immunoreactive toward CD79a, CD138, and MUM-1, and negative toward CD3 and CD20 (Figure $3 \mathrm{~B}-\mathrm{F})$. The Ki-67 proliferative index was 70\% (Figure $3 \mathrm{H}$ ), and the cells were also positive for EBV encoding region in situ hybridization. These features were suggestive of plasmablastic lymphoma. The subsequent PET-scan showed increased hypermetabolism along the right side of the nasal septum with enlarged cervical nodes. Bone marrow aspirate/trephine revealed normocellular marrow with no evidence of lymphomatous infiltration.

The patient received 6 cycles of hyperfractionated-CVAD chemotherapy. Surveillance PET-scans were performed twice within 18 months posttreatment and both did not reveal any evidence of recurrence or active disease.

\section{DISCUSSION}

PBL was first mentioned as having a strong predilection for the oral cavity of male-predominant HIV-positive patients by Delecluse et al. in $1997^{1}$. Rapid spread, extensive local invasion and poor response to treatment are the hallmarks of $\mathrm{PBL}^{2}$. Despite being astoundingly associated with HIV, few of cases have been observed in HIV-negative patients in post-transplant settings or immunosuppressed states ${ }^{2,6}$. Rare cases of PBL originating from the maxillary sinus and nasal septum have been reported in HIV-negative immunocompetent male patients ${ }^{6,7}$. It has also been argued that $\mathrm{EBV}$ is involved in the pathogenesis of $\mathrm{PBL}^{3,8}$. Laurent et al. ${ }^{8}$ proposed that EBV infection induces antiviral cytotoxic immunity, inhibits B-cell apoptosis and promotes the tolerogenic tumour microenvironment of plasmablastic lymphoma.

PBL has the unique immunohistologic features of diffuse large-cell lymphomas but with constant immunoreactivity to well-differentiated plasma cell markers such as CD138 ${ }^{1}$. It has minimal expression of leukocyte common antigen (CD45), epithelial markers, and B-cell antigens (CD20 and CD79a) which are consistently positive in other 
types of B-cell lymphomas ${ }^{1}$. Strong expression of the post-germinal centre-associated markers ie. MUM1 and CD38 is usually present, and monotypic light chain expression is frequently observed, resulting in a phenotypic pattern nearly identical to that of plasma cell myeloma ${ }^{1,2}$.

To get the tissue diagnosis, we performed examination and biopsy under GA like most of the reported cases ${ }^{6,7}$. Since hemorrhage is one of the risks, biopsy is preferably done under GA in controlled setting. The management of PBL varies widely according to discretion of the physician because any established treatment guidelines are not available in the literature, owing to rarity and aggressiveness of PBL. As for now, chemotherapy with CHOP and CVAD regimens have been used in most reported PBL cases and in our case the patient received hyperfractionated-CVAD to reduce the toxicity 9 . Philip et al. ${ }^{10}$ proposed the combination of autologous bone marrow transplant and high-dose chemotherapy which may positively improve overall survival in relapsed patients after failed treatment with multi-agent chemotherapy. Furthermore, Liu et al. ${ }^{5}$ have reported good outcome using consolidation with hematopoietic stem cell transplantation following first episode of complete remission.

Survival for Patients with PBL has lower survival rates with the median survival time being four and three months for HIV-negative and HIV-positive patients, respectively ${ }^{4}$. It has been suggested that the previously studied HIV-positive patients had better prognoses and more effective responses to chemotherapy possibly because of the administration of antiretroviral therapies, and that the older and immunosuppressed HIV-negative patients had a higher likelihood of poor organ reserve, making them weaker candidates for chemotherapy ${ }^{4}$. The present case, and other scarce number of cases in the literature ${ }^{5-7}$, are exceptional; HIV-negative, immunocompetent patients with unusual sinonasal PBL have demonstrated a good response to treatment and survived beyond a year.
In conclusion, PBL is an uncommon but aggressive large B-cell neoplasm that occurs predominantly in HIV-positive male patients or immunosuppressive hosts. To the best of our knowledge, this is the first case of nasal PBL reported in a female patient with HIV-negative and immunocompetent background, while other similar cases although sparse, were reported among males ${ }^{6,7}$. Lack of standard treatment guideline warrants further studies on PBL.

\section{REFERENCES}

1. Delecluse HJ, Anagnostopoulos I, Dallenbach F, et al. Plasmablastic lymphomas of the oral cavity: a new entity associated with the human immunodeficiency virus infection. Blood. 1997;89(4):1413-20. [CrossRef]

2. Colomo L, Loong F, Rives S, et al. Diffuse large B-cell lymphomas with plasmablastic differentiation represent a heterogeneous group of disease entities. Am J Surg Pathol. 2004;28(6):736-47. [CrossRef]

3. Castillo JJ, Bibas M, Miranda RN. The biology and treatment of plasmablastic lymphoma. Blood. 2015;125(15):232330. [CrossRef]

4. Castillo JJ, Winer ES, Stachurski D, et al. Clinical and pathological differences between human immunodeficiency virus-positive and human immunodeficiency virus-negative patients with plasmablastic lymphoma. Leuk Lymphoma. 2010;51(11):2047-53. [CrossRef]

5. Liu JJ, Zhang L, Ayala E, et al. Human immunodeficiency virus (HIV)-negative plasmablastic lymphoma: a single institutional experience and literature review. Leuk Res. 2011;35(12):1571-7. [CrossRef]

6. Saraceni C, Agostino N, Cornfield DB, Gupta R. Plasmablastic lymphoma of the maxillary sinus in an HIVnegative patient: a case report and literature review. Springerplus. 2013;2(1):142. [CrossRef]

7. Perkins JN, Chi AW, Patel NJ. Plasmablastic Lymphoma of the Nasal Septum. JAMA Otolaryngol Head Neck Surg. 2019. [CrossRef]

8. Laurent C, Gravelle P, Péricart S, et al. EBV infection promotes tumor infiltrating leucocyte and immune escape in plasmablastic lymphoma according to gene expression profiling. Hematological Oncology. 2017;35:297-298. [CrossRef]

9. Acute lymphoblastic leukemia Ph-hyperCVAD part $A$ and B/POMP treatment protocol, eviQ cancer treatment protocols, in : https://www.eviq.org.au/ haematology-and-bmt/leukaemias/acute-lymphoblastic-leukaemia/788-ph-hyper-cvad-part-a-and-bpomp-treatment-ove\#114306 [20 May 2016]

10. Philip T, Guglielmi C, Hagenbeek A, et al. Autologous bone marrow transplantation as compared with salvage chemotherapy in relapses of chemotherapysensitive non-Hodgkin's lymphoma. N Engl J Med. 1995;333(23):1540-5. [CrossRef] 